\title{
Apunts per a una lectura de la poètica de la resistència en Carmelina Sánchez-Cutillas i Vicent Andrés Estellés
}

\section{Notes on a reading of the poetic of resistance in Carmelina Sánchez- Cutillas and Vicent Andrés Estellés}

Irene Mira NaVARro

irene.mira@gcloud.ua.es

Universitat d'Alacant

Resum: El present article té per objectiu explorar la poesia dels anys seixanta de Carmelina SánchezCutillas en contrast amb la de Vicent Andrés Estellés des de l'òptica d'estudi de la «poètica de la resistència» proposada pels autors Cornelia Gräbner i David Wood (2010). D’una banda, analitzarem l'obra dels dos poetes en tant que autors que formen part de la resistència cultural durant els anys de la dictadura per formar part d'una literatura minoritzada. I, d'altra banda, estudiarem com aquesta situació imprenga el contingut dels textos i articula una «poètica de la resistència» en què les veus literàries mostren a través dels versos la seua dissensió ideològica amb l'entorn dictatorial, especialment pel que fa a la reflexió de la consciència social, de gènere i nacional.

Paraules clau: poètica de la resistència, poesia, franquisme, política, realisme

\begin{abstract}
This paper aims to explore the poetry of the 60s of Carmelina Sánchez-Cutillas in contrast with the poetry of Vicent Andrés Estellés as an example of «poetics of the resistance» proposed by the authors Cornelia Gräbner and David Wood (2010). On the one hand, we will analyze the work of the two poets like authors that form part of the cultural resistance during the years of the dictatorship because they are part of minoritised literature. On the other hand, we will study how this situation permeates the content of the texts and articulates a «poetics of resistance». The poetic voices of these authors show through the verses his ideological dissent with the dictatorial frame, especially regarding the reflection of social conscience, gender conscience and national conscience.
\end{abstract}

Keywords: poetics of resistance, poetry, francoism, politics, literary realism 
Irene Mira Navarro. Apunts per a una lectura de la poètica de la resistència en Carmelina Sánchez-

Cutillas i Vicent Andrés Estellés

\section{Introducció}

Sovint, quan ens acostem des d'un punt de vista crític a l'obra poètica dels anys seixanta de Carmelina Sánchez-Cutillas (1921-2009) s'al ludeix a la connexió de l'autora amb d'altres grans noms de la poesia catalana amb qui compareix alguns punts d'unió. Una de les vinculacions més habituals és amb Vicent Andrés Estellés (1924-1993) i amb l'entorn estètic -més aviat esteticopolític-de les propostes considerades realistes (Balaguer 1993 i Alpera 1997). En la mateixa direcció, bona part de la crítica fa entroncar els projectes literaris dels autors d'Altea i de Burjassot, a pesar de pertànyer a generacions poètiques diferents, a causa d'una representació crítica de la quotidianitat en imatges provinents de l'experiència i la memòria (Pérez Montaner 1993 i Esteve 2017).

Malgrat tot, però, ens cal una mirada de conjunt a les postures poètiques que comparteixen els dos escriptors i que els situa com a veus dissidents «des dels postulats plenament progressistes, de les circumstàncies polítiques i socials de la seua època» (Pérez Montaner 1993: 102). En aquest sentit, no podem perdre de vista que un dels elements que connecta amb més força les dues propostes literàries és la presa de consciència crítica respecte de l'entorn que els envolta i més concretament, la capacitat d'incorporar les reaccions contra la dictadura franquista present en els respectius discursos poètics (Balaguer 2000 i Lacueva 2021). Aquest aspecte és simptomàtic de la mirada de dissensió ideològica practicada pels autors; per aquest motiu, provarem de traçar un itinerari d'interpretació de les formes d'expressió del compromís polític i de com una època històrica concreta ha determinat la construcció dels subjectes poètics. Per a fer-ho, en proposarem una lectura a partir de les aportacions de Gräbner i Wood (2010) al voltant de la «poètica de la resistència». En aquest sentit, d'una banda, pararem atenció a la posició social i política de la poesia en l'entorn posterior a la postguerra valenciana i, d'altra banda, analitzarem com es tradueix la presa de posicionament crític de les veus poètiques respecte de les reflexions al voltant de les idees de classe, gènere i nació en els textos. En resum, doncs, proposem una lectura que ens permeta analitzar de quina manera en els autors «lo de afuera (la lucha social) está a dentro [del text]» (Rowe 2011: 17).

\section{2. «Sols he volgut servir el meu País»: una literatura resistent}

En fer una lectura sociològica de la literatura catalana al País Valencià en la dècada dels seixanta veurem que la figura de Carmelina Sánchez-Cutillas emergeix gràcies als esforços de l'autora per publicar dos poemaris com són Un món rebel (1964) i Conjugació en primera persona (1969). La poeta, a més, constava entre la nòmina d'autors contemplats en antologies com la de 1966 de Lluís Alpera i la de 1970 de Lo rat penat (Carbó i Simbor 1993: 50-51), i també va ser prologada en el seu segon poemari per Vicent Andrés Estellés.

La connexió, doncs, entre aquests dos autors d'edat similar però de generacions literàries distintes -Sánchez-Cutillas va publicar la seua primera obra el 1964, mentre que Estellés ja ho havia fet en 
Irene Mira Navarro. Apunts per a una lectura de la poètica de la resistència en Carmelina SánchezCutillas i Vicent Andrés Estellés

la dècada anterior- té origen en la coincidència de la intenció ètica que compartien. El pròleg de l'autor de Burjassot a Conjugació en primera persona en dona compte en al ludir a la creació de Sánchez-Cutillas. Com tot seguit veurem, entre els autors es percep una sinèrgia compartida en la praxi d'una literatura que beu de la realitat més propera i està marcada per un sentiment furiós que insinua una actitud resistent:

[...] Conjugació en primera persona és -parle per mi- el record, de fum i de crepuscle, de pols i de silenci, d'un país; d'un món, si es vol. Les gents van i venen a les seues coses i de les seues coses i, mentre fan el pa i fan l'amor, mentre fan les altes i mesquines coses de cada dia, mentre fan i desfan la vida, tenen el luxe sentimental de la nostàlgia i encenen, nocturnament, el gran foc dels garbons, el gran foc de la còlera. És un foc quasi bíblic (Andrés Estellés 1969: 11).

La còlera de Sánchez-Cutillas, nascuda a causa dels condicionants de la dictadura, es canalitza en una poesia contestatària derivada en certa manera dels preceptes realistes que havien de renovar el gènere poètic de la dècada posterior a la postguerra. Mentrestant, el projecte estellesià, engegat en la postguerra, s'allunya en alguns aspectes de l'ideari realista però manté l'atenció constant a l'esfera íntima i també a la social. Així doncs, en conjunt, els autors tenen un objectiu convergent: portar al text la realitat que els envoltava i les preocupacions polítiques que se'n derivaven a través del codi poètic. La proposta, doncs, de llegir els autors des de la poètica de la resistència descansa sobre la idea que es tracta de discursos i poetes conscients de la seua historicitat (Casas 2011: 67) com a agents d'una cultura proscrita.

Dit d'una altra manera, veiem que els projectes literaris són fruit de traduir amb un llenguatge molt personal els determinats del context social; tot deixant de banda una visió de la història construïda des de l'oficialitat i una poesia romàntica centrada únicament en l'exploració dels territoris íntims. En aquest sentit, els poetes mantenen una actitud de denúncia que es manifesta en el pla estètic però també en la funció social de la literatura. Així, doncs, en analitzar el paper cultural i polític de la poesia dels autors, d'una banda, veiem que aquesta actua com a transmissora de significats d'una cultura determinada; i d'altra banda, que el text poètic desplega una funció sociopolítica en tant que producte social. Arturo Casas ho explica així:

\footnotetext{
El primero [en referència al lloc cultural de la poesia], asociado a las prácticas y repertorios en cada cultura, entendida esta como mecanismo colectivo para la conservación y la transmisión de comunicados y para la producción de otros nuevos, según la descripción debida a la culturología de Iuri Lotman. El segundo [en referència al lloc polític de la poesia], derivado de las funciones sociopolíticas que en diferentes contextos, y con arreglo a la muy variable gradualidad de autonomia y heteronomia, se atribuyen al discurso poético. (Casas 2011: 54)
}

La proposta de Casas ens porta a proposar que el lloc polític i cultural des d'on emeten el seu discurs les veus de Sánchez-Cutillas i d'Estellés no és un altre que el de la resistència. Una resistència que s'expressa en l'escriptura del conflicte que s'articula al voltant de l'eix dominació-subalternitat (Casas 2011: 56), tot situant els autors en una posició subjugada respecte dels discursos oficials. 
Irene Mira Navarro. Apunts per a una lectura de la poètica de la resistència en Carmelina Sánchez-

Cutillas i Vicent Andrés Estellés

Arran d'aquest plantejament, considerem que tant l'autora d'Altea, com Estellés, conscients del pes de l'opressió, utilitzen el discurs testimonial -així ho fa constar també Pérez Montaner (1993: 106) sobre la consciència de gènere en Sánchez-Cutillas- per a deixar-ne constància. Gràcies a aquesta intenció els poetes donen compte dels fets d'un temps i d'un país i superen la lògica individual per a inscriure's en el grup social que reivindiquen, tal com resen aquests versos de Conjugació en primera persona:

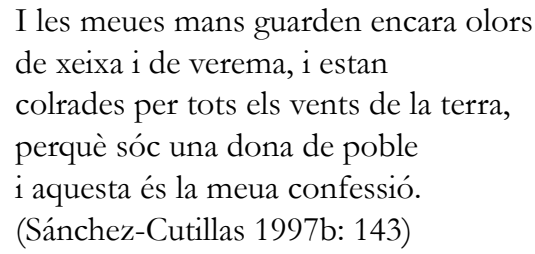

En el poema, la veu literària de l'autora es manifesta com una participant de la vida col lectiva i agrícola, la qual es testimonia a través de les mans i de la confessió que la situa com «una dona de poble». Assistim, per tant, a la incorporació als col lectius que reivindica, el poble i les dones. L’adscripció al poble també és present en el poeta de Burjassot, encara que sense la intersecció amb la categoria de gènere. Versos com els de Poemes preliminars entronquen amb la filiació de classe defensada per Sánchez-Cutillas:

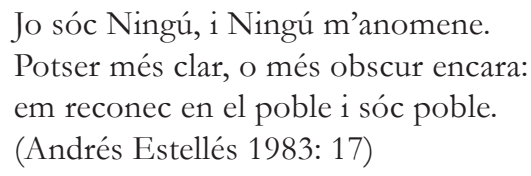

Ambdós poemes recullen la naturalesa testimonial de l'obra dels autors i la funció social que acompleix la literatura, la qual Estellés ja anunciava en versos com aquests: «sols he volgut servir les meues gents / sols he volgut servir el meu País» (Andrés Estellés 2019: 72). La voluntat de servei, doncs, de la literatura d'aquests autors manifesta l'anhel de desplegar una funció molt concreta en un context repressiu per a realitats socials, nacionals i de gènere divergents amb les que promulgava el règim.

Abans d'aprofundir en el contingut ideològic dels versos, cal parar atenció al lloc que ocupa aquesta poesia en el sistema literari de l'època. Els poetes dels anys seixanta -com a membres d'una literatura minoritzada- es troben en una posició complexa pel que fa a la situació del sistema literari, segons Enric Balaguer són «autodidactes, desvinculats de la tradició autòctona, mancats de referents clars..., són el producte resultant d'una difícil conjuntura» (1993: 22). En efecte, les dificultats amb què es troben veus poètiques provoquen que tracen itineraris d'enunciació propis i de renovació de la poesia del moment (Carbó i Simbor 1993), alguns dels quals transitaren sendes pròximes al realisme social amb la presa de posicionament crític i anhel de constituir una enunciació emancipadora que 
Irene Mira Navarro. Apunts per a una lectura de la poètica de la resistència en Carmelina SánchezCutillas i Vicent Andrés Estellés

aquest comportava. En aquest sentit, la situació de persecució i conflicte en què viuen la literatura i la cultura catalanes des de 1939 propicia que una part dels autors defensen uns postulats polítics desautoritzats pel poder $\mathrm{i}$ alhora constituisquen una xarxa de resistència que a poc a poc intentava mantindre viva la literatura catalana al País Valencià (Carbó i Simbor 1993: 25-26). Per aquest motiu parlem de poètiques resistents tant pel que fa al contingut dels versos, com a la situació dins del sistema literari.

Si ens centrem en aquest segon aspecte, el 1984 el crític Jaume Pérez Montaner afirmava que a pesar del treball que es va fer en la dècada dels seixanta, la cultura catalana al País Valencià era una «cultura de resistència» (1984: 79). Una idea lligada a la de Ferran Carbó i Vicent Simbor (1993: 43) que sentenciaven la realitat literària valenciana de l'època com un «circuit estanc» a causa de la fragilitat del sistema editorial i els canals difusió. Dit d'una altra forma, els crítics posen de manifest que a causa de l'alienació cultural i nacional a què s'havia sotmés més intensament la part meridional del país, les lletres valencianes - de les quals formen part els autors ara estudiats- esdevingueren un espai subsidiari de la cultura imperant en l'estat espanyol. En resum, Montaner afegia que, sociològicament, la situació cultural i literària al País Valencià era la d'una «cultura satèl lit»:

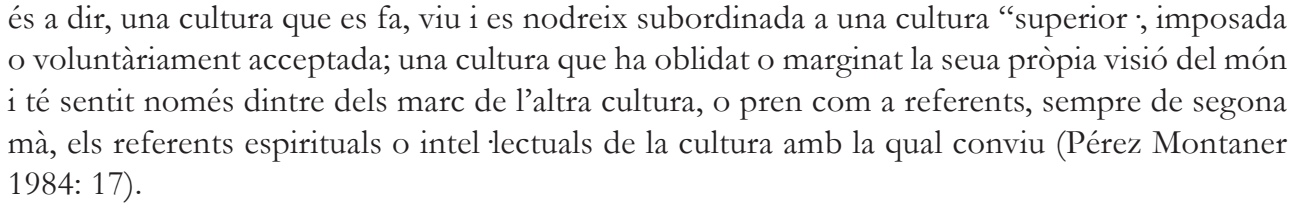

En aquest context, en què la literatura catalana escrita al País Valencià se situava als marges dels circuits culturals $\mathrm{i}$ es trobava condicionada per una cultura «superior» ressonen els ecos de la subalternitat. Encara que aquesta és una qüestió pendent i complexa d'analitzar en l'àmbit català, apreciacions recents com les de Mercè Picornell n'obrin algunes vies d'anàlisi. Per a l'estudiosa, les literatures minoritzades o que han patit processos repressius, com la dictadura franquista, són susceptibles d'acostar-se a categories d'anàlisi de la resistència en què s'entendria «el concepto de subalternidad como base de una reflexión sobre las conòmicas y tradiciones nacionales en conflicto» (Picornell i Martínez 2019: 497).

És per això que llegir la literatura catalana des d'una posició resistent a causa del conflicte amb els dictats del poder franquista ens resulta suggeridor. Particularment, Sánchez-Cutillas i Estellés confronten dialècticament amb el règim dictatorial a través del fet de l'escriptura en català i, dins d'aquesta, amb l'exercici d'una poètica resistent (Gräbner i Wood 2010) que posa en circulació un seguit de significats ideològics i d’implicació col lectiva. Algunes de les idees de Gilles Deleuze i Félix Guattari sobre les «literatures menors» recalen en aquesta direcció i, malgrat no compartir plenament les afirmacions dels filòsofs sobre les literatures petites, hi ha un aspecte sobre aquest tipus de literatures que pot abocar llum sobre la consideració «resistent» de la poesia valenciana dels seixanta. Per als autors, les literatures menors guarden una relació conflictiva i de marginalitat 
Irene Mira Navarro. Apunts per a una lectura de la poètica de la resistència en Carmelina SánchezCutillas i Vicent Andrés Estellés

respecte de les literatures majors perquè estan escrites per minories, la qual cosa provoca que en les literatures menors tot siga polític i tot tinga un valor col lectiu (Deleuze i Guattari 1990: 35-36).

Amb tot plegat, el conjunt d'aportacions crítiques suara esmentades defensa que literatures com la catalana -més especialment la del País Valencià-, minoritzades a causa del conflicte nacional actiu esdevenen circuits en esforç constant per mantenir-se vives. És en aquest marc que figures com les de Sánchez-Cutillas i Estellés encarnen la postura resistent per a la supervivència i la renovació estètica.

\section{3. «I aleshores comprenc que és impossible / evadir-me del món on sóc immersa»: el món} que assalta els textos

Com ja hem assenyalat, la situació de feblesa i arraconament que patia la literatura catalana al territori valencià permet parlar de l'escriptura dels nostres poetes com a pràctiques de resistència cultural. Aquesta realitat que afectava el sistema literari es reflecteix internament en el contingut dels poemes, que efectuen un exercici de resistència simbòlica a través del discurs.

Encara que no es tracta de llegir la literatura com una font inequívoca d'informació sociològica o històrica, proposem estudiar els aspectes socials presents en el text literari; dit d'una d'altra manera, d'indagar en la consciència de la marginalitat representada i en la presència d'allò provinent del compromís polític en la literatura. Segons el teòric de la literatura Arturo Casas, aquesta perspectiva d'anàlisi assumeix que l'ambient social és determinant en la conformació i expressió individual de les veus poètiques perquè «todo conflicto personal sustenta alguna forma latente de conflicto político, o al menos de contradicción social, cultural o conòmica» (Casas 2020: 339). Es tracta, doncs, d'explorar com un moment concret de la història ha estat capaç d'influir en la conformació dels subjectes poètics. En concret, en els treballs de Sánchez-Cutillas i d'Estellés el llast de la postguerra i el transcurs de la dictadura són dos dels fets principals que engendren d'una forma particular l'expressió del conflicte en relació a la consciència de nació, gènere i classe en els poemaris de la dècada dels anys seixanta.

En el cas de la poeta d'Altea, la inquietud subratllada en els reculls Un món rebel (1964) i Conjugació en primera persona (1969) sobre les diferents arestes de la seua identitat dona compte d'aquesta manifestació personal del desacord latent. Com ja han apuntat algunes crítiques (Francés 2015 i 2020 i Lacueva 2021), l'omnipresència d'un discurs patriarcal i opressor imperant col lideix amb l'actitud de la veu poètica, que rep l'impacte del relat del règim dictatorial en la pròpia experiència com a dona del poble. La consciència d'una posició certament marginal, de dona que escriu en català, certifica que tota una generació ha resultat marcada per les seqüeles d'uns fets històrics, com exposa el següent poema que funciona a mode de carta de presentació:

Som la inútil deixalla del segle de la por,

del segle dels silencis malmesos,

$i$ les paraules closes al recinte sense veu

SCRIPTA, Revista internacional de literatura i cultura medieval i moderna, núm. 17 / juny 2021 / pp. 504 - 519 ISSN: 2340-4841 · doi:10.7203/SCRIPTA.17.20921 
dels covards. Ens varen engendrar junt al foc de

la guerra, una nit feta clams de metralla.

(Sánchez-Cutillas 1997b: 59)

La veu poètica de l'autora es projecta com a filla de la guerra, i, en conseqüència, com un agent afectat per tota una època d'atrocitats com va ser la primera meitat del segle xx a Europa. A causa dels efectes que l'entorn provocà en la veu de l'autora, els versos esdevenen el testimoni afectiu dels successos; és per això que per a Maria Lacueva (2021: 212) els poetes «fan servir el text poètic com a mecanisme antidepressiu per tal de deixar constància del que han vist». És, aleshores, l'acció testimonial dels poemes el que permet llegir-los com el reflex artístic d'un moment determinat de la història. Així doncs, la creació poètica és, tant en Sánchez-Cutillas, com en Estellés, un producte de l'empremta que el context històric va deixar en les veus poètiques i amb una missió clara: construir un «subtext que desafia la superfície del missatge dominant» (Francés 2020). Així mateix ho remarquen aquests versos del recull $A$ mi acorda un dictat del poeta de Burjassot:

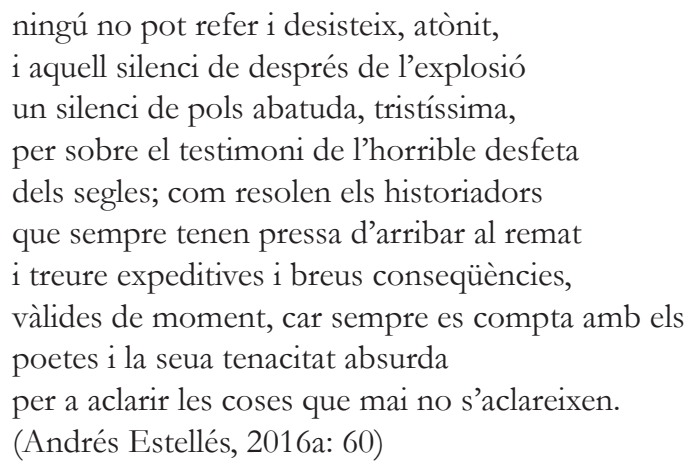

En aquests versos, la veu poètica és conscient de la seua historicitat, del caràcter històric que té allò que explica en els versos. És més, el discurs poètic es presenta com un complement al discurs dels historiadors, els quals volen conclusions però alhora necessiten dels poetes perquè aboquen llum i descodifiquen les vicissituds de la història. Per aquest motiu, considerem que l'obra dels autors és fruit d'un moviment pendular entre l'expressió individual i l'evocació cívica del conflicte, entre el jo i la història. La poètica de la resistència té lloc, doncs, en aquest punt, ja que resulta de la consonància entre l'expressió subjectiva i el compromís col lectiu en contextos polítics complexos, com és el cas dels anys de dictadura. Gräbner i Wood ho expliquen així:

The register of individuality and subjectivity that is linked with the term poetics, and the evocation of collectivity and community through the term resistance, places the practices and works under discussion in a tension between these categories. It encourages an analytical approach that considers the relationship between the work of art, the subjectivities of its creator(s) and of its recipients, and the social movements or political ideologies with which it is linked. (Gräbner i Wood 2010: 3) 
Irene Mira Navarro. Apunts per a una lectura de la poètica de la resistència en Carmelina Sánchez-

Cutillas i Vicent Andrés Estellés

Els versos esmentats d'Estellés, així com els següents de Sánchez-Cutillas, articulen un contradiscurs en referència al moment i a l'ús de la paraula: es rebel len contra el silenci i reprenen mots per a parlar d'allò negat, en definitiva, per a dotar d'existència un món prohibit com ens mostra la poeta:

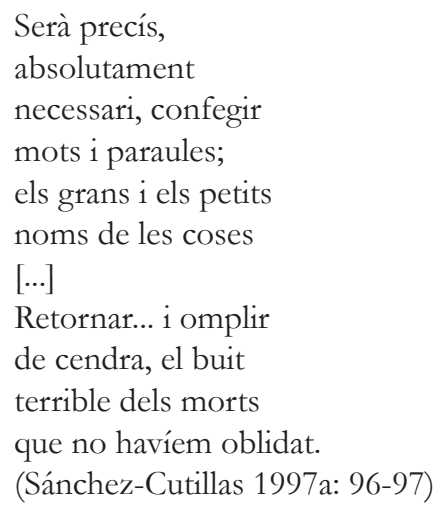

$\mathrm{Al}$ capdavall, ens trobem davant d'una pràctica poètica en què l'actitud resistent «se contrapone a una realidad determinada, hace la crítica a las representaciones en las que se sostiene esa realidad y contrapone otras representaciones más exactas» (Rowe 2011: 23). Aquestes representacions són, en efecte, les múltiples formes d'ésser perifèric que adopten les veus poètiques i que tot seguit analitzarem.

\section{4. «Som la inútil deixalla del segle de la por»: els subjectes poètics de la perifèria}

Com hem advertit anteriorment, els límits de la poesia dels anys seixanta s'eixamplen per a acollir noves imatges més enllà de les referències classicitzants i conservadores que mantenien la literatura catalana com un derivat de les estètiques oficialitzades pel règim. En concret, aquesta renovació es tradueix en la incorporació d'al lusions a la situació perifèrica de les veus poètiques pel que fa a la identitat nacional, de gènere i de classe com a element de transgressió en oposició a l'ordre imperant.

Per a traçar un recorregut de com es construeix la postura poètica dels autors cal parar atenció a dos aspectes: en primer lloc, entendre contra què es rebel len els poetes; i en segon lloc, analitzar quina és la seua proposta discursiva que dissenyen. Pel que fa al primer aspecte, hem de tindre en compte que la forja d'una condició dissident ens els poetes porta aparellats el rebuig i la negació a participar de l'ambient opressor que els ataca. Tal com resava el vers «Nosaltres no som d'eixe món» de Raimon, la poesia de Sánchez-Cutillas aprofundeix en l'antagonisme entre l'alternativa que representa la poètica de la resistència i les estructures de poder i de llei perpetrades pel règim. En Un món rebel batega aquesta intenció contestatària, la qual es materialitza en versos que situen la veu poètica en oposició a un «ells» que representa la constatació d'un enemic, si més no en el pla discursiu. Com ja han apuntat diverses crítiques (March 1997 i Cacciola 2019), el recull de Sánchez- 
Irene Mira Navarro. Apunts per a una lectura de la poètica de la resistència en Carmelina Sánchez-

Cutillas i Vicent Andrés Estellés

Cutillas és el reflex poètic d'una actitud insurrecta que utilitza la paraula per a revoltar-se contra un món imposat. Una rebel lió, però, que es gesta amb la identificació prèvia de la veu poètica amb un «nosaltres» en clara dissonància amb els conformistes i que es defineix com un conjunt «d'homes fets a la lluita de l'asfalt» $\mathrm{i}$ «ancorats a la terra». Aquesta «distància proxèmica» (Cacciola 2019: 289) entre el jo i els altres es manifesta en la constitució d'una col lectivitat resistent en què s'inclou la veu poètica, com mostren composicions com ara «Ens deien enquimerats», «Fem la visisecció», «Formem una minoria» o «Som els homes lligats». Segons Gräbner i Wood, en aquesta actitud poètica «resistance as expressed in the construction of an alternative that is positioned explicitly against existing power structures (as in 'counter-')» (Gräbner i Wood 2010: 7). Vegem com es constata la divergència respecte de les estructures establertes en la composició «Som diferents»:

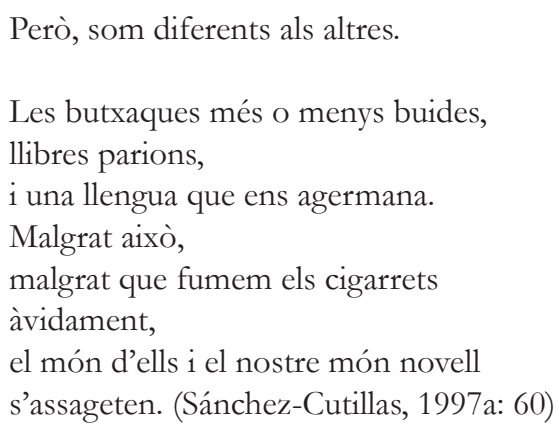

El contrast entre els dos pols, ells i nosaltres, s’associa a la distinció entre el món nou i el món vell en eterna disputa, dos ordres en contradicció que situen la veu poètica en una posició de lluita amb aquelles estructures amb qui no comparteix llengua ni normes, com es veu de nou en el poema «Res no em commou» en afirmar que ha descobert unes altres formes de llegir el món:

Tot, perquè he sentit la crida, he intuï que hi ha altres normes i altres lleis. (Sánchez-Cutillas, 1997a: 48)

La dissensió política es va gestant en l'univers poètic de Sánchez-Cutillas fins a proclamar, com déiem, l'oposició al conformisme. Els versos del poema «Havíem signat un conveni» denuncia que «els altres» tenien el pensament $\mathrm{i}$ les idees i que «els poetes, els rebels» estaven a mercè d'un pacte de silenci amb aquests:

Però eren seues les lleis

-d'aquells altres-,

i seues les paraules

que de vegades occien com

glavis roents.

SCRIPTA, Revista internacional de literatura i cultura medieval i moderna, núm. 17 / juny 2021 / pp. 504 - 519 
Irene Mira Navarro. Apunts per a una lectura de la poètica de la resistència en Carmelina Sánchez-

Cutillas i Vicent Andrés Estellés

Era un conveni secret,

per a junyir-nos

al carro del seu gregarisme.

(Sánchez-Cutillas, 1997a: 49-50)

L'absència del dret a la paraula en els poetes, és a dir, el monopoli de la paraula cedit només als conformistes, aboca a la denúncia de la negació i del silenci, la qual es manifesta més clarament amb el simple fet d'haver escrit els poemaris. Per això, l'última estrofa del poema resa «Amb tot, aquell any la Primavera / esdevindria al cor dels homes», tot posant de manifest que la presa de la paraula es desplegarà en la poeta.

En consonància amb açò, l'univers creatiu de Vicent Andrés Estellés també retorna sobre l'acte de dir com a mecanisme de resistència al silenci i de construcció de la denúncia social en L'ofici de demà:

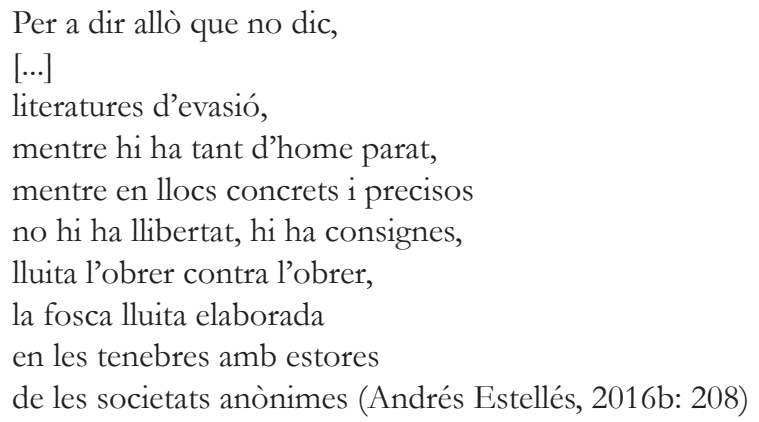

Posteriorment, el poeta continua amb el joc retòric entre dir i no dir i es presenta en qualitat de testimoni dels efectes de les estructures opressores ja apuntades en Sánchez-Cutillas. Aquest contrast entre la necessitat d'enunciació i la imposició del silenci a causa de la por recorre noves vies fins a advocar per l'ús de la paraula i el rebuig de les imposicions:

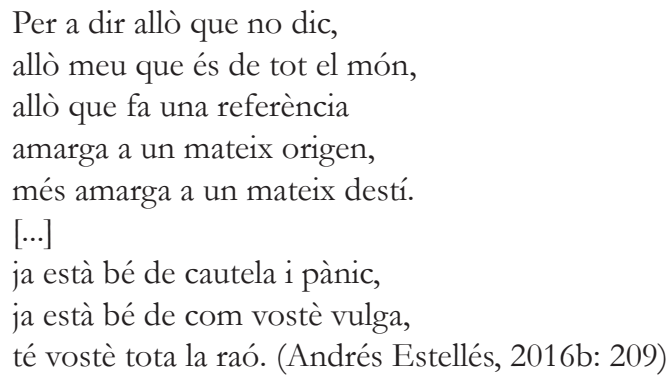

Aquest fenomen ocorre també en els versos següents de Conjugació en primera persona, en què la 
Irene Mira Navarro. Apunts per a una lectura de la poètica de la resistència en Carmelina Sánchez-

Cutillas i Vicent Andrés Estellés

consciència de gènere ${ }^{1}$ de la veu poètica es converteix en un dels reactius per les motivacions per a superar les limitacions imposades:

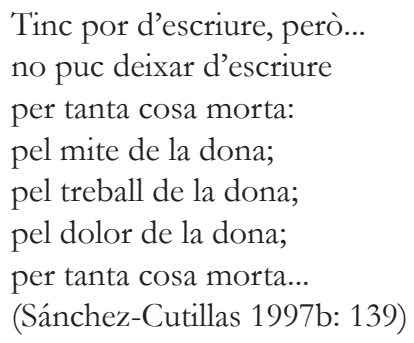

En resum, en ambdós casos s'abandona la por i es reafirma la paraula com a mitjà de contestació política i de construcció d'un discurs alternatiu des d'unes altres coordenades estètiques i ideològiques.

La constitució de l'alternativa discursiva s'observa, si posem per cas dos exemples en l'univers de Sánchez-Cutillas, en textos com ara «Fidelitat»o «Bilingüisme» de Conjugació en primera persona. Aquests poemes il lustren la complexitat de l'assumpció d'una identitat de gènere i lingüística dissident respecte de la moral patriarcal i el règim nacionalista i monolingüe del franquisme. En la primera composició, la veu poètica es qüestiona sobre la identitat de gènere, com també havia ocorregut amb el poema «Res no em salva», com a fase necessària en el camí de crear un marc discursiu alternatiu:

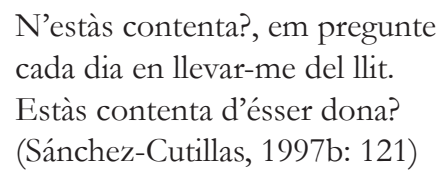

El procés del dubte i de la indagació en la forma íntima de les grans estructures, com el gènere o la nació, fa notar una actitud reflexiva i conscient sobre l'acte del rebuig d'allò imposat i de la creació de nous marcs d'actuació. Pel que fa als versos dedicats a la llengua, el dubte es reitera en reflexionar sobre el bilingüisme i concloure que aquesta pràctica es presenta com un acte de traïció a causa de la impossibilitat de conciliar les dues llengües en un estat «mesquí i subornable» que censura l'existència del català:

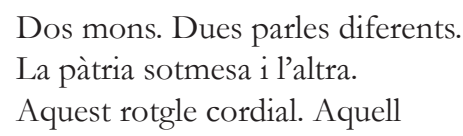

\footnotetext{
1 No focalitzarem especialment l'anàlisi sobre la consciència de gènere en l'autora a causa de les múltiples i rellevants aproximacions existents a la qüestió. Per a aprofundir en la perspectiva de gènere en l'autora vegeu els treballs de Cacciola (2019), Castellano (2020), Francés (2015 i 2020), Lacueva (2020) i Montaner (1993), entre d'altres, citats en la bibliografia final.
} 
cercle mesquí i subornable...

A qui he trait sense voler?

(Sánchez-Cutillas, 1997b: 122)

Aquestes mostres, juntament amb la vinculació afectiva i fraterna amb el conjunt de pàries i exiliats - estudiada amb deteniment per Cacciola (2019) -, manifesten inquietud i distanciament respecte del sistema normatiu i de les identitats oficials perquè «el yo lírico urde lazos de hermandad con los marginados, sujetos afines a su sensibilidad, merced a su situación social de aislamiento e inferioridad» (Cacciola 2019: 305). Aquesta identificació té lloc especialment en aquests versos d'Un món rebel:

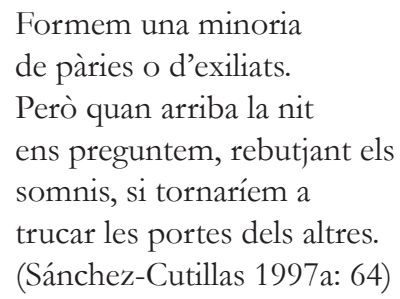

La consciència de formar part d'un grup marginat, que també podríem llegir en termes d'alteritat, dona compte de la problematització de l'adscripció nacional i de gènere present en l'autora. Aquesta consideració comporta, però, un altre procés: segons Irene Boada fets literaris com aquests són una expressió de la vivència colonitzada en les autores catalanes, les qual tenen per objectiu «the task of 'decolonising' themselvs - that is, of constructing a new gender identity» (2003: 89). L'assumpció de la marginalitat, per tant, porta aparellada des d'aquest punt de vista, la restitució d'una nova identitat que, com ja hem vist, s'allunya de les promulgades pel règim. Aquesta tendència present en algunes escriptores catalanes és apuntada per Margarida Castellanos (2020) a propòsit de Sánchez-Cutillas perquè tal com déiem: «there is a case for saying that Catalan and Irish women are doubly colonised: both by reference to their status to their nationalism. Women writer in Catalonia and Ireland have used literature to question both types of oppression» (Boada 2003: 89).

En conseqüència, l'autora usa la poesia per a un exercici triple: rebutjar uns preceptes establits pel moment històric, prendre consciència de la seua posició marginal -també dins del sistema literari i construir una nova identitat a partir d'aquesta. L'exercici s'observa amb claredat en relació al gènere, la veu poètica és clara en respondre's a la pregunta «estàs contenta d'ésser una dona?»:

\footnotetext{
Malgrat això, de matinada, retornaran a mi en silenci fidels al sexe que em donaren, al ganxet i a tot el vell einam
} 
que em defineix, que ens defineix.

(Sánchez-Cutillas 1997b: 121)

D’una forma relativament paral lela, en la poesia de Vicent Andrés Estellés l'assumpció de marginalitat també és present, encara que no per qüestions de gènere com ja hem exposat. En aquest cas, les categories problematitzades són l'adscripció a la classe i la nació. El poema «A Sant Vicent Ferrer», escrit el 1955, deixa constància de l'acció de rebuig analitzada uns paràgrafs més amunt i de la consideració que té de la literatura i del servei d'aquesta a la consciència col lectiva:

Dóna'm lluita, car no vull posar-me a adorar

els ídols imbècils de les paraules, ara

que és el temps d'agafar-les com ganivets o malls.

$[\ldots]$

Jo sóc un entre tants: em sent un entre tants

que agafen el tramvia i ploren, cada jorn,

silenciosament, quasi sense plorar.

(Andrés Estellés 2014: 206-207)

Des del rebuig als «ídols imbècils», el pensament estellesià evoluciona cap a l’adscripció al poble, entés com la col lectivitat que no forma part de la classe dominant, en un acte que es podria interpretar com un exercici de solidaritat de classe, com mostren aquests versos:

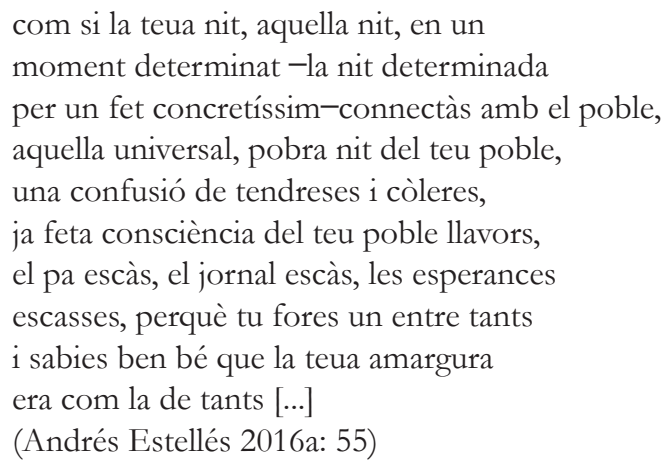

Així doncs, la unió de les veus poètiques amb els desposseïts és determinada per un compromís explícit amb aquests, la qual cosa posa de manifest que poètica i política s'entrelliguen. No obstant això, veiem que l'articulació de la resistència literària no és del tot coincident en els dos autors. Mentre que en Sánchez-Cutillas la veu poètica passa per una fase de qüestionament per a posteriorment reconèixer-se en la seua posició resistent i acollir-la humilment; en Estellés el procés de dubte no es reflecteix en la poesia sinó que assistim al rebuig inicial i a una reafirmació constant de la seua condició, com mostren els poemes. 
Irene Mira Navarro. Apunts per a una lectura de la poètica de la resistència en Carmelina Sánchez-

Cutillas i Vicent Andrés Estellés

\section{Conclusions}

A trets generals, amb aquests apunts hem intentat proposar una lectura de les formes del compromís polític i poètic dels autors estudiats. Hem observat que la situació de minorització social de la literatura catalana durant els anys de la dictadura franquista condicionà l'expressió de Carmelina Sánchez-Cutillas i Vicent Andrés Estellés com a poetes. La consideració de la creació literària en català com un acte de resistència cultural es traslladà a les formes $\mathrm{i}$ al contingut que els poetes fixaren discursivament. La consciència de pertànyer a un grup assetjat culturalment per les estructures d'estat propicià que els autors elaboraren una poètica que també es trobava impregnada de sentiments de resistència.

La configuració de les veus poètiques des dels marcs de la marginalitat, per tant, té lloc en dues direccions: d'una banda, per la dificultat inherent de ser veus d'una literatura proscrita durant una dictadura i, d'altra banda, per convertir aquesta consciència en objecte poètic i de reflexió.

Pel que fa a aquesta segona qüestió, la consideració dels projectes dels autors com a mostres de la «poètica de la resistència» ens ha permés pensar la consciència social, de gènere i nacional com a categories d'anàlisi problematitzades en les obres estudiades. Així mateix, hem vist que l'assumpció d'aquestes categories es troben en interesecció en els poetes, encara que de formes diferents. L'adscripció a una consciència resistent quant al gènere, la nació i la posició social en Carmelina Sánchez-Cutillas segueix un procés que evoluciona des de l'oposició i el rebuig a aquelles estructures imposades, com adverteixen Gräbner i Wood (2010), tot passant pel dubte i la indagació, fins arribar al reconeixement d'un nosaltres femení que escriu en català i és conscient de la identitat resistent en assumir aquestes opressions. En canvi, en Vicent Andrés Estellés, la reflexió metapoètica esdevé el mitjà per a rebutjar tot l'entramat discursiu promulgat pel poder i defensar una poètica de la resistència social i nacional que reafirma la consciència del jo poètic.

Al capdavall, tant la poeta d'Altea com el poeta de Burjassot, engeguen dos projectes literaris que convergeixen en l'assumpció d'una poètica de la resistència que expressa la consciència de les dificultats del moment de producció i que s'allunya de les prescripcions literàries i ideològiques de la dictadura per a reforçar el lloc cultural de la poesia catalana des d'una òptica ideològica molt concreta. 
Irene Mira Navarro. Apunts per a una lectura de la poètica de la resistència en Carmelina SánchezCutillas i Vicent Andrés Estellés

\section{Bibliografia}

Alpera, Ll. (1997) "Introducció", dins Sánchez-Cutillas, C. Obra poètica, València, Consell Valencià de Cultura, p. 9-36.

Andrés Estellés, V. (1969) "Pròleg. Les parets arrapades amb les ungles", dins Sánchez-Cutillas, C. Conjugació en primera persona, València, Edició pròpia, p. 9-15.

—. (1983) Poemes preliminars, Manacor, Casa de Cultura/Editorial Moll.

. (2014) "La nit", dins Andrés Estellés, V. Obra Completa Revisada. A cura de Ferran Carbó, València, 3i4, vol. I, p. 163-222.

(2016a) "A mi acorda un dictat", dins Andrés Estellés, V. Obra Completa Revisada. A cura de Vicent Salvador, València, 3i4, vol. III, p. 51-68.

—. (2016b) "L'ofici de demà", dins Andrés Estellés, V. Obra Completa Revisada. A cura de Vicent Salvador, València, 3i4, vol. III, p. 195-298.

—. (2019) "Cant temporal", dins Andrés Estellés, V. Obra Completa Revisada. A cura de Vicent Salvador i Jordi Oviedo, València, 3i4, vol. VI, p. 45-78.

Balaguer, E. (1993) “Els seixanta: el furor d'una dècada (Balanç de la poesia valenciana)”, L'Aiguadolç. Revista de literatura, 18, p. 9-22.

—. (2000) "Poesia i 'realisme històric", Caplletra. Revista internacional de filologia, 28, p. 19-32.

Boada, I. (2003) Women Write Back. Contemporary Irish and Catalan Short Stories in Colonial Context, Dublín, Irish Academic Press.

Cacciola, A. (2019), "Carmelina Sánchez-Cutillas: deconstrucción y reconstrucción identitaria femenina desde la marginación”, Lectora. Revista de dones i textualitat, 25, p. 287-306, DOI:10.1344/ Lectora2019.25.18

Carbó, F. i Simbor, V. (1993) La recuperació literària en la postguerra valenciana (1939-1972), València/ Barcelona, Institut Interuniversitari de Filologia Valenciana/Publicacions de l'Abadia de Montserrat.

Casas, A. (2011) “Teoría crítica y discurso de resistencia: lo político en la enunciación poética”, dins Casas, A. / Bolling, B. (eds.) Resistance and emancipation. Cultural and Poetic Practices, Bern, Peter Lang, p. 53-72.

- (2020) "Conflicto social, heteroglosia y poema dialógico: situación para su análisis discursivo (un regreso crítico a Bajtín y Volóshinov)", Tropelías. Revista de Teoría de la Literatura y Literatura Comparada, 7, p. 336-349.

Castellano, M. (2020) "Carmelina Sánchez-Cutillas: memòria, identitat i autobiografia", Conferència pronunciada el 24 de setembre de 2020 en Feminari. Carmelina Sánchez-Cutillas: dona rebel, València, Acadèmia Valenciana de la Llengua, disponible en https://www.youtube.com/ watch?v=tnJ5dqwxAuo [Última visita: 30/03/2021]. 
Irene Mira Navarro. Apunts per a una lectura de la poètica de la resistència en Carmelina SánchezCutillas i Vicent Andrés Estellés

Deleuze, G. i Guattari, F. (1990) “Qué es una literatura menor?”, dins Deleuze, G. / Guattari, F. Kafka. Por una literatura menor, Mèxic, Ediciones Era, p. 28-44.

Esteve, A. (2017) "Un passat on retrobar-se. Memòria i identitat en l'obra poètica de Carmelina Sánchez-Cutillas”, L'Aiguadolc. Revista de Literatura, 46, p. 29-40.

Francés, M. A. (2015) "Una travessa pel laberint: Assaig d’interpretació de Els jeroglífics i la pedra de Rosetta, de Carmelina Sánchez-Cutillas", Caplletra. Revista internacional de filologia, 58, p. 9-28, DOI: 10.7203/Caplletra.58.7135.

_. (2020) “L'estratègia de l'el lipsi: silenci i construcció d'identitat en l'obra de Carmelina Sánchez-Cutillas", Conferència pronunciada el 24 de setembre de 2020 en Feminari. Carmelina Sánchez-Cutillas: dona rebel, València, Acadèmia Valenciana de la Llengua, disponible en https:// www.youtube.com/watch? $\mathrm{v}={ }_{\mathrm{O}}$ CbebCqKfeg\&t=520s [Última visita: 30/03/2021].

Gräbner, C i Wood, D. (2010) «Introduction: The Poetics of Resistance», Cosmos and History: The Journal of Natural and Social Philosophy, 6 (2), p. 1-19.

Lacueva, M. (2021) “"Ens van engendrar junt al foc de la guerra': Les poetes davant els conflictes bèl lics del segle XX", dins Corbí, M. / Marcillas, I. (eds.) Les femmes et la guerre/Dona i guerra, Berlín, Peter Lang, p. 207-220.

March, M. Ll. (1997) "El realisme en la poesia de Carmelina Sánchez-Cutillas: Un món rebeli Conjugació en primera persona", Quaderns de filologia. Estudis literaris, 3, p. 223-236.

Pérez Montaner, J. (1984) "Literatura i fet nacional al País Valencià”, Estudi General. Revista de la Facultat de Lletres de la Universitat de Girona, 4, p. 71-81.

(1993) "Carmelina Sánchez-Cutillas: una poètica de la quotidianitat”, Revista de Catalunya, 77, p. $99-110$.

Picornell, M. i Martínez. Á. (2019) “Un gesto de escucha. De Rigoberta Menchú a las que limpian los hoteles: Aplicaciones y límites de la subalternidad en el cambio de siglo. Conversación con Mercè Picornell”, Kamchatka. Revista de análisis cultural, 14, p. 491-538, DOI: 10.7203/KAM.14.16331.

Rowe, W. (2011) "De los sujetos de la resistència y los sujetos que se resistent a resistir: sujeto lírico y emancipación", dins Casas, A. / Bolling, B. (eds.) Resistance and emancipation. Cultural and Poetic Practices, Bern, Peter Lang, p. 13-26.

Sánchez-Cutillas, C. (1997a) "Un món rebel”, dins Sánchez-Cutillas, C. Obra poètica. A cura de Lluís Alpera, València, Consell Valencià de Cultura, p. 39-106.

_ (1997b) "Conjugació en primera persona”, dins Sánchez-Cutillas, C. Obra poètica. A cura de Lluís Alpera, València, Consell Valencià de Cultura, p. 107-156. 